\title{
FINANCIAL ANALYSIS AS A STRATEGIC TOOL: THE CASE OF SMEs IN THE REPUBLIC OF KOSOVA
}

\author{
Albana BERISHA QEHAJA (i]1, Hysen ISMAJLI ${ }^{(12}$ \\ ${ }^{1}$ Department of Management and Informatics, Faculty of Economy, \\ University of Prishtina, Republic of Kosova \\ ${ }^{2}$ Department of Banking, Finance and Accounting, Faculty of Economy, \\ University of Prishtina, Republic of Kosova \\ E-mails: ${ }^{1}$ albana.berisha@uni-pr.edu; ${ }^{2}$ hysen.ismajli@uni-pr.edu (corresponding author) \\ Received 31 July 2018; accepted 30 September 2018

\begin{abstract}
This paper examines the use of financial analysis as a strategic tool in SMEs. Empirical data are collected from 303 SMEs in the Republic of Kosova, operating in production, trade and service sectors. The aim of this study is to assess the extent to which the business financial analysis is employed in the sampled enterprises and to determine whether there are differences in the usage of it, within small and medium-sized enterprises and sectors. The results show that Kosovan SMEs greatly use financial analysis as a strategic tool. Moreover, significant differences are found between small and medium-sized enterprises regarding its usage and no significant differences among production, trade and service sectors. This paper contributes to the existing scientific literature, especially in the strategic management field. Additionally, this paper will likely contribute to decision makers' increased use of business financial analysis as a strategic tool in their enterprises.
\end{abstract}

Keywords: business financial analysis, strategic tool, SMEs, transition economy, Kosova.

JEL Classification: D22, L10, L20.

\section{Introduction}

Strategic management has a long history, although the words used to describe it have changed several times as the concepts have been modified and developed (Hussey 1998). One of the most comprehensive definitions of strategic management is that of David (2011: 6) who defines strategic management, "as the art and science of formulating, implementing, and evaluating cross-functional decisions that enable an organization to achieve its objectives. As this definition implies, strategic management focuses on integrating management, marketing, finance/accounting, production/operations, research and development, and information systems to achieve organizational success". Historically, the principal benefit of strategic management has been to help organizations formulate better strategies through the use of a more systematic, logical, and rational approach for decision making (David and David 2017).
The strategic-level support tools offered to executives are diverse and come from many different disciplines (Stenfors et al. 2007). In essence, all of these tools and techniques are prescriptions that are supposed to make it possible to choose improved organizational outcomes and results well in advance of acting (Stacey 2012). David and David (2017) highlight that firms with management systems that utilize strategic-planning concepts, tools, and techniques generally exhibit superior long-term financial performance relative to their industry. Helfert (2001) emphasized that financial analysis is an essential toolkit for analytically oriented persons of any viewpoint, as they judge the financial/economic performance and outlook of any business.

Admittedly the private sector development is very important for the country's economic development. Small and medium enterprises (hereinafter referred to as SMEs) represent the largest business sector in any world economy

Copyright $\odot 2018$ The Authors. Published by VGTU Press.

This is an Open Access article distributed under the terms of the Creative Commons Attribution License (http://creativecommons.org/licenses/by/4.0/), which permits unrestricted use, distribution, and reproduction in any medium, provided the original author and source are credited.. 
(Culkin and Smith 2000). SMEs are important engines to stimulate the economic growth of a country (Van Gils 2005). Despite their contribution to the economy in terms of turnover and number of jobs created, SMEs are often neglected in books about strategy (Phillips and Moutinho 2018). Also, to date, clearly is a lack of knowledge on the applicability of strategic management tools and techniques in SMEs (Pasanen 2011).

To fully benefit from strategic positive effects on firm performance the SMEs should use the strategic tools and techniques (Gică and Balint 2012). One of the most used tools by SMEs in developing countries is business financial analysis (Berisha Qehaja et al. 2017b). It is considered as one of the most important functions in the organization (Alexander 2018). It is an art and also a skill which can be facilitated and assisted by learning various techniques that have been developed by those seeking to understand financial information (O’Regan 2016).

According to the resource-based model, differences in firms' performances across time are due primarily to their unique resources and capabilities rather than to the industry's structural characteristics (Hitt et al. 2009). The development of a resource-based view has played a major role in the renewal of strategic planning practice (Grant 1991, Barney 1991, Glaister and Falshaw 1999). Thus, investigating the use of strategic tools for better competitiveness and performance is considered a resource-based approach.

Lately, Laamanen (2017) in the article, "Reflecting on the past 50 years of Long Range Planning and a research agenda for the next 50", calls for further research on some topic areas, including strategic management in different contexts (strategy processes or practices in emerging and developed market contexts and in different company contexts) and strategy tools. Hereupon, through this research we are trying to make a modest contribution in this aspect.

Consequently, a number of general questions arise. Do the Kosovan SMEs use financial analysis as a strategic tool? Is there any difference in usage by different sized enterprises and sectors? We endeavoured to answer these questions, which are based upon responses from 303 SMEs.

Drawing upon the general literature of strategic management, the focus of the paper is thus:

- To assess the extent to which the financial analysis is employed in the sampled enterprises.

- To determine whether there are differences in the usage of financial analysis, among small and medium-sized enterprises.

- To determine whether there are differences in the usage of financial analysis, among trade, production and service sector.

This paper contributes to the existing scientific literature, especially in the strategic management field. Firstly: this study is likely to contribute to decision makers in increasing the financial analysis usage in their enterprises since there are many benefits from using it. Secondly: it pinpoints the usage of financial analysis as a strategic tool by different sized enterprises and sectors in the Republic of Kosova as a transition economy.

The paper is organized into four sections. The first section provides a brief literature review on strategy and strategic tools, business financial analysis and small and medium-sized enterprises. Then, proceed with the development of hypotheses. Further, section two sets out the research methods of the study. The research design was cross-sectional and data were collected using structured questionnaires based on a survey strategy. Section three presents statistical findings and discussion. In the final section, the concluding remarks and limitations are given.

\section{Theoretical insights}

\subsection{The nature of strategy and strategic tools}

The literature on strategic management provides a number of different perspectives and assumptions, with increasing attempts to define what strategy is and where it comes from - esoteric debates that are often impenetrable and largely irrelevant to practitioners (Tassabehji and Isherwood 2014). Phillips and Moutinho (2018) think that strategy is the kernel of the strategic management field. A co-word analysis study for the period $1962-2008$ by Ronda-Pupo and Guerras-Martin (2012) found that the essence of the strategy concept is the dynamics of the firm's relation with its environment, for which the necessary actions are taken to achieve its goals and/or increase performance by means of the rational use of resources (as cited by Phillips and Moutinho 2018: 27). Dess et al. (2014) define strategy as the ideas, decisions, and actions that enable a firm to succeed. Surely, strategy does not exist in a vacuum, and has both an influence on and is influenced by the culture of the organisation, its structure and the people it employs (Hussey 1997). As well, strategy is all about being different. Sustainable competitive advantage is possible only by performing different activities from rivals or performing similar activities in different ways (Dess et al. 2014)

In literature, we encounter various definitions of strategic management. Hitt et al. (2009: 6) underline that, "the strategic management process is the full set of commitments, decisions, and actions required for a firm to achieve strategic competitiveness and earn above-average returns". According to Dess et al. (2014), strategic management consists of the analyses, decisions, and actions an organization undertakes in order to create and sustain competitive advantages. Nag et al. (2007: 944) surveyed academics that are part of Business Policy and Strategy Division, articles published in Strategic Management Journal or both of them. They concluded that strategic management can be defined 
as "the major intended and emergent initiatives taken by general managers on behalf of owners, involving utilization of resources to enhance the performance of firms in their external environments".

Strategic management is the art and science of formulating, implementing, and evaluating cross-functional decisions that enable an organization to achieve its objectives (David 2011). Nevertheless, firms have a greater commitment to formulation aspects of strategy and relatively less commitment to the implementation and evaluation of strategy (Glaister and Falshaw 1999).

Many argue that the global change towards the knowledge economy has major implications for the strategic management of organizations (Stacey 2007). The speed of change is forcing companies to implement strategic management processes that are permanent, in-house, and constantly revised (Planellas 2013). Moreover, strategic management allows an organization to be more proactive than reactive in shaping its own future; it allows an organization to initiate and influence (rather than just respond to) activities - and thus to exert control over its own destiny (David and David 2017).

Over the last hundred years business-school researchers and management consultants have developed a plethora of tools and techniques to be used by leaders and managers (Stacey 2012). Jarzabkowski and Kaplan (2015) guess that the list is too long to enumerate. Otherwise, Clark (1997) thinks that there is no comprehensive list of strategic tools. Even though there have been some attempts to classify strategic tools (Prescott and Grant 1988, Webster et al. 1989, Clark 1997, Vaitkevičius 2006, Lisiński and Šaruckij 2006, Stacey 2012, Wright et al. 2013). Newly, Vuorinen et al. (2017) made a review of strategy tools published in leading journals within the past 25 years. They classified a total of 88 tools on the basis of the phase of the strategic management process in which the tool might be most useful. As claimed by them, the largest group of tools (48) comprises methods aiding strategy architecture, 37 target strategic action and a small number (3) help to evaluate the performance of the current strategy.

"Strategy tool" is used as a generic name for any method, model, technique, tool, technology, framework, methodology or approach used to facilitate strategy work (Stenfors et al. 2007) and provide decision support (Clark and Scott 1999). Strategic management tools and techniques that claim to support strategic decisions can be found at least in the following fields: systems science, systems thinking, operations management, logistics, industrial engineering, decision support systems, expert systems, knowledge management, management information systems, executive information systems, artificial intelligence, business intelligence, online analytical processing, enterprise systems, marketing, accounting, and finance (Stenfors et al. 2007). In addition to the theoretical approaches and frameworks provided by academics and consultants, many articles provided vivid examples of how different companies were implementing long range planning and what kind of analytical tools and approaches they were using (Laamanen 2017).

Strategy tools also can be described as concepts that assist strategic managers in decision making (Gunn and Williams 2007). Thus, Ackoff (2003) stated that leaders can be more effective by learning about the management tools and techniques available to them and how to use them. According to Pasanen (2011), the purpose of strategic management tools and techniques is to offer significant gains and benefits for the company using the tools. Whereas, Stacey and Mowles (2016) convincingly argue that systemic tools and techniques are often used on special occasions such as strategy 'away-days' or when large numbers are involved in highly visible problems.

\subsection{Business financial analysis}

Good financial management has three major aims: to keep the business solvent, to maintain sufficient liquidity for it to meet liabilities as they become due, and to ensure that in the context of these first two aims it provides the company in the most efficient way with the finance it needs for growth. A company which practices strategic management will be trying to meet these aims more effectively - a way that is future-oriented, considers more factors, is better coordinated, and which should make it possible for better financial decisions to be made. Just as strategic planning as a whole sets out to be a better way of running a business, financial planning - one of its components - sets out to be more effective in managing the finance function (Hussey 1998). However, it is generally agreed in theory that the main financial goal of the firm is maximizing shareholders' value (Pandey 1995).

According to Alexander (2018), financial analysis is one of the most important functions of the organization. Moreover, O'Regan (2016:251) states that, "financial information analysis is an art. It is a highly subjective exercise where the experience and intuition of the user are critical factors. However, it is also a skill. It can be facilitated and assisted by learning various techniques that have been developed by those seeking to understand financial information". Whereas, according to Akkizidis and Stagars (2016), financial analysis plays a key role in managing concentration and systemic risks.

Financial information is presented in various forms. Financial statements, such as the balance sheet, income statement and cash-flow statement that are found in an annual report, are probably the most common means by which financial information is made available (O'Regan 2016). Also, according to Alexander (2018), the three primary financial statements are the income statement, the 
balance sheet, and the statement of cash flows. He stresses out that we need all three statements to properly understand and evaluate financial performance. Furthermore, Helfert (2001) differentiates between purely financial analysis on one hand, and economic analysis and trade-offs on the other. According to him, the first is largely based on financial statements and accounting data, while the second focuses on cash flows.

In financial analysis, time plays a central role. This means that time exists as a background dimension within the entire financial system. However, there are two parallel time dimensions in financial analysis: one is about the exact times set in contractual agreement; it also defines the historical actual financial event and the present point in time where the future starts. The other dimension is the simulated and reported time. It refers to times, usually expressed as intervals, where we are considering the calculation and reporting of the financial events. Any calculation process of financial events follows this time dimension (Akkizidis and Stagars 2016).

While published financial statements are the most widely available source for financial analysis, the limitations inherent in their preparation (based on generally accepted accounting principles) require a basic understanding on the part of the user of how analytical results in the areas of performance and valuation can be distorted and what adjustments may be necessary (Helfert 2001). According to Alexander (2018), financial analysis does not properly capture the strategic value. If the financials do not fully reflect the strategic case and expected synergies, then they should be revised.

Financial analysis can be viewed as the decision-making process of financial analysts (Grüber 2015). Whilst, Stacey (2012) considers that tools and techniques should be categorized into four main groups: the tools of instrumental rationality, the techniques of power, institutional techniques and the techniques of practical judgment. He points out that the financial analysis falls into the category of instrumental rationality tools, particularly into decision-making and monitoring and control tools subgroups.

Small and medium-sized enterprises

Maintaining competitive success or even surviving over long periods of time is indeed very difficult for companies of any size (Dess et al. 2014). Successful organizations today tend to figure out what they are really best-in-class at and ensure that their capabilities are aligned with marketplace opportunities. The opportunities actually pursued are not solely based on external market analysis using financial metrics, but based upon internal capabilities such as knowledge, people, processes, systems and tools that can create enhanced levels of stakeholder value (Phillips and Moutinho 2018).
Admittedly the SMEs are very important for the country's economic development. They represent the largest business sector in any world economy (Culkin and Smith 2000). SMEs are important engines to stimulate the economic growth of a country (Van Gils 2005). According to Phillips and Moutinho (2018), despite their contribution to the economy in terms of turnover and number of jobs created, SMEs are often neglected in books about strategy.

According to Ayyagari et al. (2007), the SME contribution to GDP in Australia is 23\%, in New Zealand 35\%, 52\% in the UK, $48 \%$ in the US, around $57 \%$ in Denmark, Canada and Japan, in Luxembourg around 76\%, Germany nearly $43 \%$, Greece around $28 \%$, Italy around 59\%, and Slovenia around $17 \%$. Whereas according to Ministry of Trade and Industry (2011), the contribution of Kosovan SMEs to GDP is nearly $40 \%$.

The process of strategic planning has been investigated in some detail during the last thirty years (Aldehayyat and Anchor 2009). According to Ates and Bititci (2009), literature highlights that strategy is managed in SMEs from an informal and intuitive fashion with a fire fighting approach, shortterminism. Even according to Stonehouse and Pemberton (2002), in practice, SMEs are more oriented towards short-term operational issues than long-term strategic decisions and decicion-making is more reactive than proactive. While Smith and Smith (2007) address limited SMEs success in weak strategic planning skills, shortsightedness, and lack of focus on external and strategic issues.

According to the Ministry of Trade and Industry in Kosova $(2011,2013,2015)$, the role of the private sector, especially SMEs have been relatively weak. Nevertheless, Kosova are still in the transition phase in which entrepreneurship and small business creation is expected to play an important role on the road to a modern economy, free market and thus towards development and economic growth.

Categorization of enterprises in Kosova is done according to Law no. 2005/02-L5 and Law 03/L-031 to support SMEs. The number of headcounts is the sole criterion for classification of Kosovan enterprises. Also, this is in accordance with the enterprises 'classification by the European Union ${ }^{1}$.

Out of a total of 103,755 registered enterprises in the Republic of Kosova: 102,070 (or 98.37\%) are micro enterprises; $1,406(1.35 \%)$ are small; $221(0.22 \%)$ are medium; and, only $58(0.06 \%)$ are classified a large (Ministry of Trade and Industry (2011). Based on data from the Tax Administration of Kosova (TAK), the total turnover of SMEs in 2010 was $€ 1,693,926,734.31$ or $43.30 \%$ of GDP. The total turnover of all businesses was $€ 2,222,485,094.15$ (56.81\% of GDP) (Ministry of Trade and Industry, 2011).

\footnotetext{
1 1-9 headcounts-micro enterprise, 10-49 headcounts - small enterprise, 50-249 headcounts - medium enterprise and over 250 headcounts - large enterprise.
} 
Therefore, given the previous discussions, it is hypothesized that:

Hypothesis 1: There is a significant difference in the usage of financial analysis, among small and medium-sized enterprises.

Hypothesis 2: There is a significant difference in the usage of financial analysis, among trade, production and service sector.

\section{Research methodology}

The research design was cross-sectional and data were collected using structured questionnaires based on a survey strategy. The questionnaire is considered as one of the most widely used data collection techniques in business research (Cooper and Schlinder 2014) and within business and management research, the greatest use of questionnaires is made within the survey strategy (Saunders et al. 2009).

The population size of this study was 1,685 enterprises, so we set a 95 percent certainty and a margin of error of 5 percent, so the sample size resulted in 573 enterprises $^{2}$. Out of total 573 enterprises included in the sample, surveys were conducted in 314 of them. Since the target population of this empirical study were SMEs in the Republic of Kosova, we excluded large enterprises. Consequently, this study is based on data from 303 SMEs (from them 251 small and 52 medium-sized enterprises) and the respondents were owners/managers who were directly involved in top management. Accordingly, the total response rate was nearly 55 percent ${ }^{3}$. For most academic studies involving top management representatives, it is reasonable to have a response rate of 35 percent (Baruch 1999).

Sampling was selected through random method, extracted from the final database of the Tax Administration of Kosova. Considering the large disproportion between small and medium-sized enterprises, a stratified sampling method was applied and as the stratum is set the size of the enterprise.

The survey was carried out during the period of November 2016-January 2017. The data were analyzed using the SPSS statistical program (version 23.0), which is commonly used by researchers in social sciences research.

\subsection{Constructs measures}

Financial analysis. To measure the level of respondents' knowledge on financial analysis, several questions are included in the questionnaire. It is considered that an enterprise

\footnotetext{
2 Sample size calculation is done online at http://www.raosoft.com/samplesize.html. The guidelines for calculating stratified random sample are taken from the article "How to Get a Stratified Random Sample: Steps", http://www.statisticshowto.com/stratified-random-sample/.

3 The total response rate is calculated based on the guidelines of Saunders et al. (2009: 220).
}

uses this tool if it uses at least one of the following means as income statement, the balance sheet, or the statement of cash flows.

To investigate the level of respondents' knowledge on financial analysis, the metering criterion has been adapted from Jarzabkowski et al. (2012). Thus, respondents have been given the opportunity to indicate: $1=$ they have never heard of, $2=$ they have heard of but do not use, $3=$ they have used previously but do not use now, and $4=$ they are currently using.

Enterprise size. As mentioned earlier, the number of headcounts is the sole criterion for classification of Kosovan enterprises, which is in accordance with the enterprises 'classification by the European Union. Therefore, the enterprise size as a variable is measured as the natural logarithm of a firm's total number of employees. In the same manner, this variable has been measured in previous studies (Glaister et al. 2008). This measuring scale produces ordinal data.

Sector. Like enterprise size, the sector as a variable is present almost in most of the studies, at least as a structural characteristic of a sample. Since this empirical study includes three main sectors in Kosova, namely the trade, production and service sector, the measurement of them is done using dummy variables. This measuring scale produces nominal data.

For testing $\mathrm{H}_{1}$ and $\mathrm{H}_{2}$, the non-parametric test Kruskal Wallis was used, which is a one-way analysis of variance by ranks and it assumes random selection and independence of samples. According to Cooper and Schlinder (2014), this test is a generalized version of the Mann-Whitney test and is used to determine whether there are statistically significant differences between two or more groups of an independent variable. If the test results in a $(p)$ value equal to or less than 0.05 , the result is significant and shows a statistically significant difference between the categories. If the $(p)$ value results greater than 0.05 , it indicates that there are no significant differences between the categories.

The formula for calculating the Kruskal Wallis $\mathrm{H}$ test is as follows:

$$
H=\frac{12}{N(N+1)} \sum_{j=1}^{k} \frac{T_{j}^{2}}{n_{j}}-3(N+1),
$$

where, $T_{j}=$ sum of ranks in column $j ; n_{j}=$ number of cases in $j$ th sample; $N=\sum w j=$ total number of cases; $K=$ number of samples.

\section{Results and discussion}

Out of total enterprises $(n=303), 82.8 \%(n=251)$ were small-sized enterprises, $17.2 \%(n=52)$ were medium-sized enterprises. Meanwhile, 30.7\% $(n=93)$ belonged to the production sector, $30.7 \%(\mathrm{n}=93)$ belonged to the trade sector and $38.6 \%(n=117)$ to the service sector. 
As mentioned earlier, to investigate the level of respondents' knowledge on financial analysis, the metering criterion has been adapted from Jarzabkowski et al. (2012). The results are presented in the following figure (Figure 1).

The results show that Kosovan SMEs highly use financial analysis as a strategic tool. The results are approximately similar among small and medium enterprises. Nearly $90 \%$ of them uses it regularly. Only $2-3 \%$ of them never heard of it. There is a difference among SMEs regarding the answer have heard of but do not use it. Two percent (2\%) of smallsized enterprises have chosen this answer, respectively $6 \%$ of medium-sized enterprises. Meanwhile, $4-5 \%$ of them have answered that have used previously, but do not use now. Although to see if there is any statistical difference among SMEs, the tests are applied only to enterprises that have used financial analysis, and the significance criterion is assigned as $\alpha=0.05$. The first alternative and null hypotheses are presented in the following:

$\boldsymbol{H}_{1}$ : There is a significant difference in the usage of financial analysis, among small and medium-sized enterprises.

$\boldsymbol{H}_{\mathbf{0}}$ : There is no significant difference in the usage of financial analysis, among small and medium-sized enterprises.

In the following table (Table 1) are the results of the Kruskal Wallis $\mathrm{H}$ test.

Table 1. The usage of business financial analysis by enterprise size

\begin{tabular}{|c|c|c|c|}
\hline \multicolumn{4}{|l|}{ 1a. Ranks } \\
\hline & Enterprise size & $\mathrm{N}$ & Mean Rank \\
\hline \multirow{3}{*}{$\begin{array}{l}\text { Business } \\
\text { financial } \\
\text { analysis }\end{array}$} & $\begin{array}{l}\text { Small-sized enter- } \\
\text { prises }\end{array}$ & 225 & 132.04 \\
\hline & $\begin{array}{l}\text { Medium-sized } \\
\text { enterprises }\end{array}$ & 46 & 155.35 \\
\hline & Total & 271 & \\
\hline \multicolumn{4}{|c|}{$\begin{array}{l}\text { 1b. Test statistics } \\
\text { Test Statistics }{ }^{\mathrm{a}, \mathrm{b}}\end{array}$} \\
\hline & \multicolumn{3}{|c|}{ Business financial analysis } \\
\hline Chi-Square & \multicolumn{3}{|l|}{4.196} \\
\hline Df & \multicolumn{3}{|l|}{1} \\
\hline Asymp. Sig. & \multicolumn{3}{|l|}{.041} \\
\hline \multicolumn{4}{|c|}{ a. Kruskal Wallis Test } \\
\hline \multicolumn{4}{|c|}{ b. Grouping Variable: Enterprise size } \\
\hline
\end{tabular}

The results of the Kruskal-Wallis $\mathrm{H}$ test shows that there is a statistically significant difference in the usage of financial analysis, among small and medium-sized enterprises $\left(\chi^{2}(1\right.$, $N=271)=4.196, p=0.041$ ), with a mean rank of 132.04 for small-sized enterprises, and 155.35 for medium-sized enterprises. Based on the results of this test, there is a statistically significant difference in the usage of financial analysis by enterprise size, because $\mathrm{p}<0.05$. So, the first hypothesis is supported.

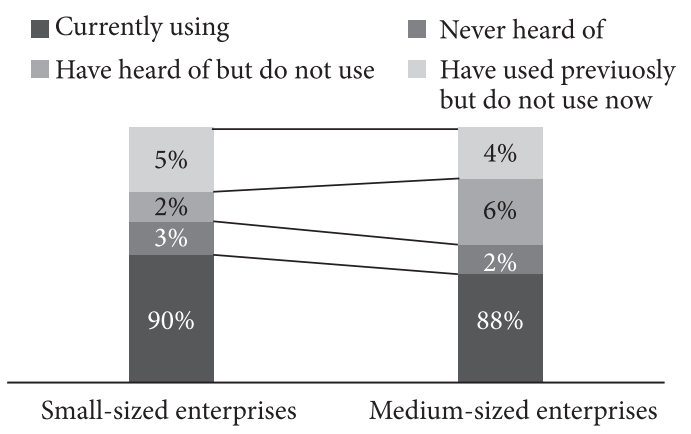

Figure 1 . The usage of financial analysis by enterprise size



Figure 2. The usage of financial analysis by sectors

The second alternative and null hypotheses are presented in the following:

$\mathrm{H}_{2}$ : There is a significant difference in the usage of financial analysis, among trade, production and service sector.

$\boldsymbol{H}_{\mathbf{0}}$ : There is no significant difference in the usage of financial analysis, among trade, production and service sector.

To check whether there are differences between enterprises of different sectors related to the use of financial analysis, in the following Figure (Figure 2), first is presented the comparison of the financial analysis usage by sectors.

The results are approximately similar among sectors. On average, $89 \%$ of them use financial analysis tool and nearly $11 \%$ of them do not use it. The results show that the trade sector enterprises use mostly this tool, then comes the production sector, following by the service sector. Although to see if there is any statistically significant difference among sectors, the tests are applied only to enterprises that have used financial analysis, and the significance criterion is assigned as $\alpha=0.05$.

The results of the Kruskal-Wallis $\mathrm{H}$ test in Table 2 show that there is no statistically significant difference in the usage of financial analysis, among production, trade and service enterprises $\left(\chi^{2}(2, N=271)=0.372, p=0.830\right)$, with a mean rank of 139.72 for production enterprises, 145.46 for trade enterprises and 139.69 for service enterprises.

Results of a review of empirical studies using textual narrative synthesis method for the period 1990-2015, conducted by Berisha Qehaja et al. (2017a), point out that business 
Table 2. The usage of business financial analysis by sectors

\begin{tabular}{|c|c|c|c|}
\hline \multicolumn{4}{|l|}{ 2a. Ranks } \\
\hline & Sector & $\mathrm{N}$ & Mean Rank \\
\hline \multirow{4}{*}{$\begin{array}{l}\text { Business } \\
\text { financial } \\
\text { analysis }\end{array}$} & Production & 83 & 139.72 \\
\hline & Trade & 85 & 145.46 \\
\hline & Service & 103 & 139.69 \\
\hline & Total & 271 & \\
\hline \multicolumn{4}{|c|}{$\begin{array}{l}\text { 2b. Test statistics } \\
\text { Test Statistics }{ }^{\mathrm{a}, \mathrm{b}}\end{array}$} \\
\hline & \multicolumn{3}{|c|}{ Business financial analysis } \\
\hline Chi-Square & \multicolumn{3}{|l|}{.372} \\
\hline Df & \multicolumn{3}{|l|}{2} \\
\hline Asymp. Sig. & \multicolumn{3}{|l|}{.830} \\
\hline \multicolumn{4}{|c|}{ a. Kruskal Wallis Test } \\
\hline \multicolumn{4}{|c|}{ b. Grouping Variable: Sector } \\
\hline
\end{tabular}

financial analysis is one of the most used tools in SMEs. Moreover, Stonehouse and Pemberton (2002) surveyed 159 SMEs in the UK, and business financial analysis resulted as the most used tool. Same were the results of Aldehayyat and Anchor (2009) and Aldehayyat et al. (2011) conducted in 83 respectively in 40 Jordanian enterprises. Also, O'Brien (2009) conducted an empirical research in 143 enterprises in world level, including UK, Europe, USA, Australia, New Zealand, Africa, etc. and the second most used tool resulted business financial analysis.

As seen earlier, a significant difference has been found in the use of financial analysis among small and medium enterprises. Also, it should be noted that the larger the enterprise the greater the rate of financial analysis usage. These findings are consistent with the results of previous empirical studies which also point out that large enterprises use more strategic tools (Stonehouse and Pemberton 2002, Elbanna 2007, Aldehayyat and Anchor 2009, Aldehayyat et al. 2011, Pasanen 2011, Kalkan and Bozkurt 2013, Rigby and Bilodeau 2015).

Whereas, the findings show that there is no significant difference in financial analysis usage by sectors in Kosovan enterprises. Likewise, the results emerged in the studies conducted by Glaister and Falshaw (1999), Stonehouse and Pemberton (2002), Aldehayyat and Anchor (2009) and Elbanna (2007). While Kalkan and Bozkurt (2013) have found significant differences among sectors in Turkey regarding the use of strategic tools.

\section{Concluding remarks}

The view of accountants, many academics and, of course, analysts, therefore, is that even if it is not possible to develop a strategy that secures superior returns to the market over the long term, fundamental analysis is a legitimate and rewarding exercise. It offers one means of identifying firms that offer abnormal returns, since an ability to understand the implications of various accounting alternatives provides a competitive advantage to the user (O'Regan 2016).

The contemporary literature points out that SMEs are creators of new products, new jobs, generators of economic development, market and competition. It is also argued that they are flexible, adaptable to the market, react quickly and easily fit the environment. Therefore, the rapid development of SMEs implies the follow-up to the same shift in the education system in line with the needs of the private sector.

This study is likely to contribute to decision makers in increasing the financial analysis usage in their enterprises since there are many benefits from using it. Also, it pinpoints the usage of financial analysis as a strategic tool by different sized enterprises and sectors in the Republic of Kosova, as a transition economy. Accordingly, two hypotheses have been set. Hypothesis 1 assumed that there is a significant difference in the financial analysis usage by small and mediumsized enterprises. The research results supported $\mathrm{H}_{1}$. While hypothesis 2 assumed that there is a significant difference in the financial analysis usage by production, trade and service enterprises. The research results did not support $\mathrm{H}_{2}$.

There are a number of other potential areas for future research that might provide significant value. Therefore, the following limitations are recommended to be taken into account in future research.

Since this study has focused only on Kosovan SMEs and was cross-sectional, further studies with a focus on large enterprises over time need to be done. In addition, it is recommended that future studies on the current topic are to be done in other developing countries because the results might not be extendable to other countries. Also, the financial analysis should be deeper operationalized including contemporary means of it.

\section{References}

Ackoff R (2003) The opportunity quest separates real leaders from managers. Strategy \& Leadership 31 (5): 39-40. https:// doi.org/10.1108/sl.2003.26131eab.001

Akkizidis I, Stagars M (2016) Marketplace lending, financial analysis, and the future of credit: integration, profitability, and risk management. John Wiley \& Sons. https://doi. org/10.1002/9781119099437

Aldehayyat JS, Anchor JR (2009) Strategic planning tools and techniques in Jordan: awareness and use. Strategic Change 17 (7-8): 281-293. https://doi.org/10.1002/jsc.833

Aldehayyat JS, Al Khattab AA, Anchor JR (2011) The use of strategic planning tools and techniques by hotels in Jordan. Management Research Review 34 (4): 477-490. https:// doi.org/10.1108/01409171111117898

Alexander J (2018) Financial planning \& analysis and performance management. John Wiley \& Sons. https://doi. org/10.1002/9781119491460 
Ates A, Bititci U (2009) Strategy dynamics in small to mediumsized enterprises: evidence from UK manufacturing SMEs. In: 16th International European Operations Management Association Conference, 14-17 June, Göteborg, Sweden.

Ayyagari M, Beck T, Demirguc-Kunt A (2007) Small and medium enterprises across the globe. Small Business Economics 29 (4): 415-434. https://doi.org/10.1007/s11187-006-9002-5

Barney JB (1991) Firm resources and sustained competitive advantage. Journal of Management 17 (1): 99-120. https:// doi.org/10.1177/014920639101700108

Baruch Y (1999) Response rate in academic studies - a comparative analysis. Human Relations 52 (4): 421-438. https://doi. org/10.1177/001872679905200401

Berisha Qehaja A, Kutllovci E, Shiroka Pula J (2017a) Strategic management tools and techniques usage: a qualitative review. Acta Universitatis Agriculturae et Silviculturae Mendelianae Brunensis 65 (2): 585-600. https://doi.org/10.11118/ actaun201765020585

Berisha Qehaja A, Kutllovci E, Shiroka Pula J (2017b) Strategic management tools and techniques: a comparative analysis of empirical studies. Croatian Economic Survey 19 (1): 67-99. https://doi.org/10.15179/ces.19.1.3

Clark DN (1997) Strategic management tool usage: a comparative study. Strategic Change 6 (7): 417-427.

Clark DN, Scott JL (1999) Strategic level MS/OR tool usage in the United Kingdom and New Zealand: a comparative survey. Asia-Pacific Journal of Operational Research 16 (1): 35-51. https://doi.org/10.1057/jors.1995.148

Cooper DR, Schindler PS (2014) Business research methods. New York: McGraw-Hill Irwin.

Culkin N, Smith D (2000) An emotional business: a guide to understanding the motivations of small business decision takers. Qualitative Market Research: An International Journal 3 (3): 145-157. https://doi.org/10.1108/13522750010333898

David FR (2011) Strategic management concepts and cases $\left(13^{\text {th }}\right.$ ed) Prentice Hall International, Inc.

David FR, David FR (2017) Strategic management: a competitive advantage approach. Pearson Education.

Dess GG, Lumpkin GT, Eisner AB, McNamara G (2014) Strategic management: Text and cases ( $7^{\text {th }}$ ed) New York: McGraw-Hill.

Elbanna S (2007) The nature and practice of strategic planning in Egypt. Strategic Change 16 (5): 227-243. https://doi. org/10.1002/jsc.797

Gică OA, Balint CI (2012) Planning practices of SMEs in North-Western region of Romania - an empirical investigation. Procedia Economics and Finance 3: 896-901. https:// doi.org/10.1016/S2212-5671(12)00247-X

Glaister KW, Falshaw JR (1999) Strategic planning: still going strong? Long Range Planning 32 (1): 107-116. https://doi. org/10.1016/S0024-6301(98)00131-9

Glaister KW, Dincer O, Tatoglu E, Demirbag M, Zaim S (2008) A causal analysis of formal strategic planning and firm performance: evidence from an emerging country. Management Decision 46 (3): 365-391. https://doi. org/10.1108/00251740810863843

Grant RM (1991) The resource-based theory of competitive advantage: implications for strategy formulation.
California Management Review 33 (3): 114-135. https://doi. org/10.2307/41166664

Grüber S (2015) Intangible values in financial accounting and reporting: an analysis from the perspective of financial analysts. Springer.

Gunn R, Williams W (2007) Strategic tools: an empirical investigation into strategy in practice in the UK. Strategic Change 16 (5): 201-216. https://doi.org/10.1002/jsc.799

Helfert EA (2001) Financial analysis: tools and techniques: a guide for managers. New York: McGraw-Hill, 221-296.

Hitt MA, Ireland RD, Hoskisson RE (2009) Strategic management concepts \& cases: competitiveness and globalization. Cengage Learning.

Hussey DE (1997) Strategic management: from theory to implementation. Butterworth-Heinemann, England.

Hussey DE (1998) Strategic management: from theory to implementation. Oxford: Butterworth-Heinemann.

Jarzabkowski P, Kaplan S (2015) Strategy tools-in-use: a framework for understanding "technologies of rationality" in practice. Strategic Management Journal 36 (4): 537-558. https://doi.org/10.1002/smj.2270

Jarzabkowski P, Giulietti M, Oliveira B, Amoo N (2012) "We don't need no education" - or do we? Management education and alumni adoption of strategy tools. Journal of Management Inquiry 22 (1): 4-24. https://doi. org/10.1177/1056492612460588

Kalkan A, Bozkurt ÖÇ (2013) The Choice and use of strategic planning tools and techniques in Turkish SMEs according to attitudes of executives. Procedia-Social and Behavioral Sciences 99: 1016-1025. https://doi.org/10.1016/j.sbspro.2013.10.575

Laamanen T (2017) Reflecting on the past 50 years of Long Range Planning and a research agenda for the next 50. Long Range Planning 50 (1): 1-7. https://doi.org/10.1016/j.lrp.2017.02.001

Lisiński M, Šaruckij M (2006) Principles of the application of strategic planning methods. Journal of Business Economics and Management 7 (2): 37-43. https://doi.org/10.1080/1611 1699.2006.9636122

Ministry of Trade and Industry (2011) SME development strategy for Kosovo 2012-2016 (with vision to 2020). Prishtina.

Ministry of Trade and Industry (2013) Strategy for private sector development 2013-2017. Prishtina.

Ministry of Trade and Industry (2015) 15 years of transition in Kosovo: Implications for trade. Prishtina.

Nag R, Hambrick DC, Chen MJ (2007) What is strategic management, really? Inductive derivation of a consensus definition of the field. Strategic Management Journal 28 (9): 935-955. https://doi.org/10.1002/smj.615

O'Brien F (2009) Supporting the strategy process: a survey of UK OR/MS practitioners. Journal of the Operational Research Society 62 (5): 900-920. https://doi.org/10.1057/jors.2011.2

O'Regan P (2016) Financial information analysis: the role of accounting information in modern society. Routledge.

Pandey IM (1995) Essentials of financial management ( $4^{\text {th }}$ ed) Vikas Publishing House. 
Pasanen M (2011) Strategic management tools and techniques in SMEs. In: Society of Interdisciplinary Business Research (SIBR) 2011 Conference on Interdisciplinary Business Research. https://doi.org/10.2139/ssrn.1867897

Phillips P, Moutinho L (2018) Contemporary issues in strategic management. Routledge.

Planellas M (2013) In search of the essence of strategy, a model for strategic management in three stages. ESADE Business School Research Paper, 3-26. https://doi.org/10.2139/ssrn.2353362

Prescott JE, Grant JH (1988) A manager's guide for evaluating competitive analysis techniques. Interfaces 18 (3): 10-22. https://doi.org/10.1287/inte.18.3.10

Rigby D, Bilodeau B (2015) Management tools \& trends 2015. London, Bain \& Company.

Ronda-Pupo GA, Guerras-Martin LÁ (2012) Dynamics of the evolution of the strategy concept 1962-2008: A co-word analysis. Strategic Management Journal 33 (2): 162-188. https:// doi.org/10.1002/smj.948

Saunders M, Lewis P, Thornhill A (2009) Research methods for business students. Pearson Education.

Smith MH, Smith D (2007) Implementing strategically aligned performance measurement in small firms. International Journal of Production Economics 106 (2): 393-408. https:// doi.org/10.1016/j.ijpe.2006.07.011

Stacey RD (2012) Tools and techniques of leadership and management: Meeting the challenge of complexity. Routledge. https://doi.org/10.4324/9780203115893

Stacey RD, Mowles CH (2016) Strategic management and organisational dynamics: the challenge of complexity to ways of thinking about organisations $\left(7^{\text {th }}\right.$ ed) Pearson Education.
Stacey RD (2007) Strategic management and organisational dynamics: the challenge of complexity to ways of thinking about organisations $\left(5^{\text {th }}\right.$ ed) Pearson Education.

Stenfors S, Tanner L, Syrjänen M, Seppälä T, Haapalinna I (2007) Executive views concerning decision support tools. European Journal of Operational Research 181 (2): 929-938. https://doi. org/10.1016/j.ejor.2006.06.024

Stonehouse G, Pemberton J (2002) Strategic planning in SMEs some empirical findings. Management Decision 40 (9): 853-861.

Tassabehji R, Isherwood A (2014) Management use of strategic tools for innovating during turbulent times. Strategic Change 23 (1-2): 63-80. https://doi.org/10.1002/jsc.1960

Vaitkevičius S (2006) Modelling of strategic analysis in strategic management. Engineering Economics 4 (49): 37-47 http:// inzeko.ktu.lt/index.php/EE/article/view/11430

Van Gils A (2005) Management and governance in Dutch SMEs. European Management Journal 23 (5): 583-589. https://doi. org/10.1016/j.emj.2005.09.013

Vuorinen T, Hakala H, Kohtamäki M, Uusitalo, K (2017) Mapping the landscape of strategy tools: a review on strategy tools published in leading journals within the past 25 years. Long Range Planning. https://doi.org/10.1016/j.lrp.2017.06.005

Webster JL, Reif WE, Bracker JS (1989) The manager's guide to strategic planning tools and techniques. Planning Review 17 (6): 4-48. https://doi.org/10.1108/eb054273

Wright RP, Paroutis SE, Blettner DP (2013) How useful are the strategic tools we teach in business schools? Journal of Management Studies 50 (1): 92-125. https://doi.org/10.1111/j.14676486.2012.01082.x 